\title{
TEORI-TEORI KEPEMIMPINAN
}

\author{
Ghufron \\ Universitas Zainul Hasan Genggong Probolinggo Jawatimur \\ Mahasiswa Program Doktoral IAIN Jember \\ gufron,maksum123@,gmail.com
}

\begin{abstract}
ABSTRAK
Teori-teori dalam kepemimpinan diantaranya adalah pendekatan karakter (Trait Approaches), pendekatan perilaku (Style Approaches), pendekatan kontingensi (Contingency Approaches), teori kepemimpinan transaksional an teori kepemimpinan transformasional. Selain itu, teori kontingensi yang dikemukakan oleh Fiedler, Yukl juga mengemukakan bahwa perilaku pemimpin dapat meningkatkan kinerja kelompok karna dapat mempengaruhi variable intervening (usaha dan kerja tim) yang dapat mempengaruhi kinerja kelompok. Sedangkan Teori Vroom dan Yetton mengemukakan bahwa kepuasan dan prestasi disebabkan oleh perilaku bawahan yang pada gilirannya dipengaruhi oleh perilaku atasan, karakteristik dan faktor lingkungan.
\end{abstract}

Kata kunci: pendekatan karakter, pendekatan perilaku, pendekatan kontingensi

\section{PENDAHULUAN}

Salah satu faktor penting untuk mencapai kesuksesan dalam suatu organisasi adalah ditentukan oleh kepemimpinan. Di berbagai situasi, suatu tim, unit militer, lembaga pendidikan atau bahkan organisasi relawan ditentukan oleh kualitas pemimpinnya. Seorang pemimpin haruslah mempunyai sifat kepemimpinan. Sifat kepemimpinan ini menjadi hal yang mutlak bagi seorang pemimpin dalam memimpin organisasinya.

Kepemimpinan merupakan pengikat dalam suatu kelompok dan pemberi motivasi untuk tercapainya tujuan organisasi. Tanpa kepemimpinan yang efektif (baik formal maupun informal) individu maupun kelompok cenderung tidak memiliki arah .

FENOMENA, Vol.19 No.1April 2020 | 73 


\section{KONSEP KEPEMIMPINAN}

Pengertian kepemimpinan menurut beberapa para ahli antara lain: Pertama, menurut Robbins yang dikutip oleh Sudarwan Danim dan Suparno: kepemimpinan adalah kemampuan memengaruhi kelompok kearah pencapaian tujuan. ${ }^{1}$ Kemampuan sebagai kegiatan untuk memengaruhi orang-orang yang diarahkan terhadap pencapaian tujuan organisasi. ${ }^{2}$ Kepemimpinan adalah kemampuan dan kesiapan seseorang untuk dapat memengaruhi, mendorong, mengajak, menggerakkan dan bila perlu memaksa orang lain agar orang itu mau menerima pengaruh dan berbuat sesuatu untuk membentuk proses pencapaian tujuan yang telah ditetapkan. ${ }^{3}$

Intinya seorang pemimpin harus mampu memberikan dorongan kepada anggota kelompoknya untuk bekerja dengan penuh rasa tanggung jawab serta dapat bekerjasama untuk mencapai tujuan organisasi yang telah ditetapkan.

\section{Pendekatan Karakter (Trait Approaches)}

Karakter adalah ciri pribadi pemimpin yang menonjol seperti kejujuran, kecerdasan, kemampuan menyelesaikan tugas, dan bahkan penampilan.

Pendekatan Karakter (Trait Approaches) ini mengatakan bahwa pemimpin itu dikenal melalui sifat-sifat pribadinya. Seorang pemimpin pada umumnya akan ditentukan oleh sifat-sifat jasmaniah dan rohaniahnya. Oleh karena itu, sangat penting mengetahui kaitan antara keberhasilan seorang pemimpin dengan sifat-sifatnya. ${ }^{4}$

\section{Pendekatan Perilaku (Style Approaches)}

Pendekatan Perilaku (Style Approaches) menekankan analisis perilaku pemimpin, mengidentifikasi elemen-elemen kepemimpinan yang dapat dikaji, dipelajari, dan dilaksanakan. Pada umumnya kepemimpinan itu dapat

\footnotetext{
${ }^{1}$ Sudarwan Danim dan Suparno, Managemen dan Kepemimpinan Transformasional Kepala Sekolah: Visi dan Strategi Sukses Era Tehnologi, Situasi Krisis, dan Internalisasi Pendidikan (Jakarta: Renika Cipta, 2009), h. 3.

${ }^{2}$ Mulyasa, Manajemen Berbasis Sekolah: Konsep, Strategi, dan Implementasi (Bandung: PT. Remaja Rosdakarya, 2004), h. 107.

${ }^{3}$ Marno dan Triyo Supriyatno, Manajemen dan Kepemimpinan Pendidikan Islam (Bandung: Refika Aditama, 2008), h. 30.

${ }^{4}$ Veithzal Rivai dan Sylviana Murni, Education Management: Analisis Teori dan Praktek (Jakarta: Rajawali Pers, 2012), h.286
}

74 | FENOMENA, Vol.19 No.1April 2020 
dipandang sebagai suatu proses, melalui orang lain yang dipengaruhi oleh pemimpin tersebut mencapai tujuan organisasi. ${ }^{5}$

Para peneliti di Ohio State University mengidentifikasi dua perilaku utama yang dimiliki oleh pemimpin yaitu pertimbangan (consideration) dan struktur permulaan (initiating stucture). ${ }^{6}$

\section{Transactional Leadership dan Transformational Leadership}

Karakteristik kepemimpinan transaksional ditunjukkan oleh tiga dimensi, yaitu contingensi reward (imbalan kontingensi), active management by exception (manajemen eksepsi aktif), dan passive avoidant. Sedangkan dalam kepemimpinan transformasional diuraikan dalam empat ciri utama yaitu kharisma, motivasi inspirasional, , stimulasi intelektual dan konsiderasi individual.

\section{Pendekatan Kontingensi (Contingency Approaches)}

Teori kontingensi kepemimpinan pertama yang terkenal dikemukakan oleh Fiedler yang mengambil pendekatan mencocokkan pemimpin dengan situasi di mana ia akan sukses. Model kontingensi yang dihasilkan menyatakan bahwa keefektifan seorang pemimpin tergantung dari tiga variabel yaitu: struktur kebutuhan pemimpin, kendali situasi pemimpin, interaksi antara struktur kebutuhan pemimpin dan kendali situasi. ${ }^{7}$

Selain teori kontingensi yang dikemukakan oleh Fiedler, Yukl juga mengemukakan bahwa perilaku pemimpin dapat meningkatkan kinerja kelompok karna dapat mempengaruhi variable intervening (usaha dan kerja tim) yang dapat mempengaruhi kinerja kelompok. ${ }^{8}$ Sedangkan Teori Vroom dan Yetton mengemukakan bahwa kepuasan dan prestasi disebabkan oleh perilaku bawahan yang pada gilirannya dipengaruhi oleh perilaku atasan, karakteristik dan faktor lingkungan. Komponen utama dalam efektifitas pemimpin adalah kemampuan mengambil keputusan yang sangat menentukan keberhasilan tujuan organisasi. ${ }^{9}$

\section{Kepemimpinan Kepala Sekolah yang Ideal}

Kepemimpinan merupakan salah satu faktor yang menentukan keberhasilan dan kemenangan dalam suatu organisasi. Kemenangan kecil

\footnotetext{
5 ibid, h.287

${ }^{6}$ Materi slide

${ }^{7}$ Amirullah, Pengantar Manajemen (Jakarta: Mitra Wacana Media, 2015), h. 171

${ }^{8}$ Materi slide

${ }^{9}$ Materi slide
}

FENOMENA, Vol.19 No.1April 2020 | 75 
bisa saja dapat diperoleh seorang diri, akan tetapi kemenangan besar yang pada akhirnya menentukan keberhasilan dalam mencapai tujuan organisasi, tidak akan dapat diperoleh dengan seorang diri. Dengan kata lain, untuk mencapai keberhasilan organisasi, pemimpin membutuhkan orang lain. Oleh karena itu, seorang pemimpin harus benar-benar paham tentang kepemimpinannya.

Pada teori sifat mengatakan bahwa seorang pemimpin harus mempunyai siat-sifat yang unggul, sehingga dapat memimpin orang lain. Pada teori perilaku, pendekatan efektivitas kepemimpinan melalui teori sifat kurang dapat menjelaskan terhadap perilaku pemimpin dalam mencapai tujuan organisasi. Pada teori situasional, seorang pemimpin lahir dari situasi yang ada dan kemudian mempengaruhi orang lain menuju suatu perubahan sesuai dengan tuntutan situasi yang ada. Sedangkan pada teori transformasional, seorang pemimpin mampu mentransformasi budaya lama menuju budaya baru yang lebih baik.

Kepemimpinan dalam dunia pendidikan berkaitan dengan masalah kepala sekolah dalam memimpin para guru untuk mencapai visi dan misi sekolah. Dalam hal ini perilaku kepala sekolah mampu mendorong kinerja para guru dengan menunjukkan rasa bersahabat, dekat, penuh perhatian, penuh pertimbangan terhadap guru, baik secara inividu maupun secara kelompok.

Kinerja kepemimpinan sekolah merupakan upaya kepala sekolah dalam mengimplementasikan manajemen sekolah guna mewujudkan tujuan pendidikan secara efektif dan efisien. Oleh karena itu kepala sekolah memiliki posisi yang penting dalam menggerakkan manajemen sekolah agar dapat berjalan sesuai kebutuhan zaman, khususnya kemajuan ilmu pengetahuan, teknlogi, agama, budaya, dan seni.

Pada dasarnya tugas kepala sekolah sangat luas dan kompleks. Rutinitas kepala sekolah menyangkut serangkaian pertemuan interpersonal yang berkelanjutan dengan murid, guru, orang tua, atasan, dan pihak-pihak terkait lainnya. Kepala sekolah merupakan sosok yang berada pada garis terdepan dalam mengoorganisasikan elemen-elemen di bawahnya agar dapat meningkatan mutu pembelajaran. Kepala sekolah merupakan guru senior yang menduduki jabatan tertentu.

Kepala sekolah haruslah mempunyai kualiatas tertentu dalam mencapai tujuan pendidikan. Pertama, kepala sekolah haruslah memahami

76 | FENOMENA, Vol.19 No.1April 2020 


\section{Ghufron}

visi dan misi lembaga yang dipimpinnya. Dengan memahami visi dan misi lembaga yang dipimpinnya, menjadikan kepala sekolah tahu persis apa yang ingin dicapai oleh lembaga tersebut, sehingga program-program yang dilaksanakan terarah dan jelas.

Kedua, kepala sekolah harus mempunyai kompetensi-kompetensi tertentu dalam mewujudkan visi dan misi sekolah. Mencakup kompetensi kepribadian, kompetensi manajerial, kompetensi kewirausahaan, kompetensi supervisi, dan kompetensi sosial.

Jika melihat teori-teori kepemimpinan di atas, seorang kepala sekolah haruslah mempunyai sifat-sifat yang unggul dalam menjalankan roda kepemimpinannya, baik sifat rohaniahnya maupun sifat jasmaniahnya. Kepala sekolah haruslah memiliki karakter yang mencerminkan integritas dalam mencapai visi dan misi sekolah. Dua perilaku utama yang dianggap penting bagi kepemimpinan adalah perilaku yang berorientasi tugas dan perilaku yang beroientasi manusia.

Kepala sekolah sebagai pemimpin harus dapat mengenal dan memahami kedudukan, keadaan, dan apa yang diinginkan, baik oleh guru maupun oleh pegawai tata usaha serta anggota lainnya dan dapat bekerjasama dengan baik sehingga dapat menghasilkan pikiran yang harmonis dalam usaha perbaikan sekolah. Kegagalan sekolah mencerminkan gagalnya perilaku serta peranan kepemimpinan seorang kepala sekolah. Dalam hal ini, perlu menjadi bahan pertimbangan bagi kepala sekolah dalam menggerakkan seluruh anggota yang dipimpinnya.

Pada teori kontengnsi Fiedler menyatakan bahwa kunci utama dari keberhasilan kepemimpinan terletak pada gaya dasar kepemimpinannya. Yaitu, gaya kepemimpinan yang berorientasi pada tugas dan gaya kepemimpinan yang beorientasi pada hubungan pimpinan dan bawahan. Dalam teorinya, untuk mengukur gaya kepemimpinan seorang pemimpin dapat menggunakan LPC (Least Preferred Coworker - teman kerja yang paling tidak disukai).

Efektivitas kepemimpinan kepala sekolah tergantung pada dua hal yaitu pemilihan gaya kepemimpinan yang tepat untuk menghadapi situasi tertentu dan tingkat kedewasaan para bawahan yang dipimpinnya. Kematangan jiwa (kedewasaan) bukan sebatas usia atau emosional melainkan sebagai keinginan untuk menerima tanggung jawab, dan kemampuan serta pengalaman yang brubungan dengan tugas.

FENOMENA, Vol.19 No.1April 2020 | 77 
Selain itu, kepala sekolah harus mampu mengelola semua anggotanya secara efektif dan efisien untuk mencappai visi dan misi sekolah serta membawa lembaga yang dipimpinnya menjadi lembaga yang berkualitas. Kepala sekolah harus mampu mentrasformasi paradigma lama kepada paradigma baru yang lebih baik. Teori kepemimpinan yang dapat diterapkan adalah kepemimpinan transformasional. Kepemimpinan transformasional mengandung empat pokok yaitu pengaruh idealisme (idealized influence), konsiderasi individual (individualized consideration), stimulasi intelektual (intellectual stimulation), dan motivasi inspirasional (inspirational motivation).

\section{PENUTUP}

Peranan pemimpin dalam suatu organisasi sangatlah penting karena keberadaan pemimpinan menjadi salah satu tombak dari keberhasilan dalam beroganisasi. Kajian mengenai teori-teori kepemimpinan dapat digunakan dalam menjalankan kepemimpinan yang efektif. Pada teori sifat mengatakan bahwa seorang pemimpin harus mempunyai siat-sifat yang unggul, sehingga dapat memimpin orang lain. Pada teori perilaku, pendekatan menjelaskan perilaku pemimpin dalam mencapai tujuan organisasi. Pada teori situasional, seorang pemimpin lahir dari situasi yang ada dan kemudian mempengaruhi orang lain menuju suatu perubahan sesuai dengan tuntutan situasi yang ada. Sedangkan pada teori transformasional, seorang pemimpin mampu mentransformasi budaya lama menuju budaya baru yang lebih baik.

Selain teori sifat, teori perilaku, teori kepemimpinan transaksonal dan teori kepemimpinan transformasional, terdapat juga teori kontingensi fiedler, teori kepemimpinan Yulk dan teori kepemimpinan Vroom dan Yetton. Keefektifan kepemimpinan kepala sekolah dapat mengacu dan mengombinasikan teori-teori di atas.

78 | FENOMENA, Vol.19 No.1April 2020 


\section{Ghufron}

\section{DAFTAR PUSTAKA}

Amirullah. 2015. Pengantar Manajemen. Jakarta: Mitra Wacana Media

Danim, Sudarwan dan Suparno. 2009. Managemen dan Kepemimpinan Transformasional Kepala Sekolab: Visi dan Strategi Sukses Era Tehnologi, Situasi Krisis, dan Internalisasi Pendidikan. Jakarta: Renika Cipta

Daft, L Richard. 2011. Era Baru Manajemen.Edisi ke 9. Diterjemahkan oleh: Tita Maria Kanita. Jakarta: Salemba Empat

Khusnuridlo. 2017. Leadership. Jember : Pascasarjana IAIN Jember (Materi slide)

Marno dan Triyo Supriyatno. 2008. Manajemen dan Kepemimpinan Pendidikan Islam. Bandung: Refika Aditama

Mulyasa. 2004. Manajemen Berbasis Sekolah: Konsep, Strategi, dan Implementasi. Bandung: PT. Remaja Rosdakarya

Rivai, Veithzal dan Sylviana Murni. 2012. Education Management: Analisis Teori dan Praktek. Jakarta: Rajawali Pers 